\title{
Islam and Girls’ Education: Obligatory or Forbidden
}

\author{
Sumaira T. Khan \\ University of Iowa, Iowa, USA
}

\begin{abstract}
“Acquisition of knowledge is binding on all Muslims” (al-Sunan 1:81 §224). This Hadith, sayings or actions of the prophet Muhammad (MPBUH) ${ }^{1}$, indicates that there is no preference based on sex in getting access to education in Islam; however, there is a growing misconception among the people of other religions that Islam constrains Muslim girls from getting education. This paper reviews literature and two authentic sources of Islamic scriptures, which are the Holy Qura'an and the Ahadith to position the girls' education in purview of Islam. It further examines the possible reasons for conflicting interpretations of Islamic teachings. It concludes that Islam does not restrict girls from getting education. It recommends further systematic studies for exploring the reasons for the projection of distorted images of Islam.
\end{abstract}

Keywords: Islam and girls’ education, cultural effects on education

\section{Introduction}

Islam is a religion of peace (Bush, 2001), justice, and equality (Ji, Ibrahim, \& Kim, 2009). However, there seems to be a growing distorted image of Islam around the globe. Among many other issues, Islam is viewed as a religion in which women are restricted from many basic rights, including education because of the persistent low girls' literacy rate among Muslim societies. This paper reviews the fundamental Islamic guiding Authorities, the holy Qura'an and the compilations of Ahadith ${ }^{2}$ (the traditions of the prophet Muhammad, MPBUH) to address the research question of whether or not Islam restricts girls from education. It reviews the literature to describe the Islamic viewpoint of education and to answer the question of how scholars have responded to the apparent restricted attitude of males towards girls' education in Muslim societies. The purpose of this paper is to understand the perspective of Islam on girls' education and to contribute to literature on Islam.

\section{Methodology}

This study employed critical theory with a focus on feminism and an Islamic framework to analyze verses from Qura'an, Ahadith, and literature. In order to review the literature about the stance of Islam on girls' education and the reasons for discouraging attitudes towards girls' education among the Muslims, databases such as EBSCOhost, ProQuest Dissertation and Theses, and PsycINFO were searched. Though there was relatively less literature available on the search words, around 70 articles, dissertations, and editorials were shortlisted for detailed review. Ten out of 70 were found to be more relevant than others. These were the articles, which addressed the issue of girls' education specifically, whereas the foci of others were issues on

Sumaira T. Khan, doctoral candidate in educational leadership at the University of Iowa, University of Iowa.

Correspondence concerning this article should be addressed to Sumaira T. Khan, 437 Hawkeye Drive, Iowa City, Iowa, 52246.

1 May peace be upon him.

2 Plural of Hadith, saying of prophet Muhammad (MPBUH) is Ahadith. 
terrorism or the images of Islam. Moreover, there are many compilations of Ahadith, but only a few are well accepted by scholars and are known as authentic Ahadith. Those include Al-Jami' alsahih (meaning; the authentic collection) and Kitab al-sunan (meaning; the book of traditions), so efforts have been made to include Ahadith from the agreed upon compilations only. It may also be noted that most of the translators, from the 17th century to the 21st century, of Qura'an and Ahadith from Arabic to English are male scholars (Abukari, 2014). They acknowledge the fact that Arabic as a language is complex and one word may have many meanings, depending on the context. Moreover, "semitic ${ }^{3}$ languages do not have a gender neutral pronoun" (Zaid, 2011). He further has argued that "He" (huwa) is the default pronoun in Arabic and does not have to imply the masculinity of the subject. "She" (hiya) on the other hand refers explicitly to a female subject. Efforts have been made to quote the most agreed upon translation of the verse. However, while including a Hadith, the main message is being given preference over the use of male or female pronouns in some cases because of the above stated reason. Moreover, different researchers have spelled Qura'an differently; for example, some spell it as Quran, others spell it as Koran so they are quoted as original in this paper.

This paper is organized in three parts. First part discusses the Islamic stance on girls' education followed by Islamic perspective on education. Finally it goes on to explore the reasons other than religion for low literacy rates of girls among Muslim societies. It concludes with some recommendations.

\section{Islamic Stance on Girls’ Education in the Light of Qura'an and Hadith}

This section starts with the verses from Qura'an about knowledge and the gender-neutral language of those verses because "the Koran is at the core of the faith and its laws" (Afsher, 2007, p. 420). The first verses of the Quran begin with the word:

Read. Read in the name of thy Lord who created; [He] created the human being from blood clot. Read in the name of thy Lord who taught by the pen: [He] taught the human being what he did not know. (96: 1-5)

In chapter 39, l-zumer, Qur’an says, “Are those who have knowledge equal to those who do not have knowledge?” (Verse 9)

The analysis of the above verses reveals that Allah ordains the responsibility of acquiring knowledge to human beings regardless of their sex, age, or race.

Moreover, Allah says in the Qur'an, “And Allah has brought you out from the wombs of your mothers while you know nothing. And He gave you hearing, sight, and hearts that you might give thanks (to Allah)” (An-Nahl, 78). The link of the key words (knowing nothing and giving thanks) in the two sentences of the above is a clear indication of exploration and seeking knowledge. It may be noticed that there is no preferred sex indication in the verse.

Similarly, the Prophet Muhammad (MPBUH) has also emphasized the significance of seeking knowledge on various occasions. For example, the prophet said, "seeking knowledge is obligatory upon every Muslim..." (Saheeh al-Jaami', 3914). Another Hadith, which is not authentic but highly referred to in Islamic discourses, commands to "seek knowledge from the cradle to the grave" (Multaqa Ahl al Hadeeth). Hence this rules out the span of time period for seeking knowledge. "Seeking knowledge even if it is in as far as China" (Multaqa Ahl al Hadeeth), is equally referenced Hadith, though controversial in terms of authenticity. There are many

\footnotetext{
${ }^{3}$ A subfamily of Afroasiatic languages that include Akkadian, Arabic, Aramaic, Ethiopic, Hebrew, and Phoenician (dictionary definition).
} 
interpretations of this Hadith; some agree that the implicit meaning was knowledge of science because at the time (7th century AD), China was scientifically developed and had invented some writing tools. Others believe a geographical interpretation that a Muslim has to travel if it is necessary for acquiring knowledge. They link their argument with another Hadith that says, "If death comes to the student of knowledge while he is thus engaged, he dies as a martyr" (Al-Bazzar). Islam insists on acquiring knowledge from any source. For example, he said, "Wisdom is the lost property of the believer, he should take it even if he finds it in the mouth of a mushrik." Mushrik means non-Muslim.

There are examples in which the Prophet exemplified his teachings. For instance, in the very first battle between the believers and unbelievers in Mecca, known as the Jang-e-Badr, the Muslims won and caught 70 non-Muslims as prisoners of war (POW). The Prophet put the condition of teaching ten Muslim children how to read and write for releasing literate POW. Again, it may be noted that there was no sex preference. Children meant both girls and boys.

In Al-Jami’ alsahih, Abu Musa Al-Ashari narrated that, “The Prophet said, 'he who has a slave-girl and teaches her good manners and improves her education and then manumits and marries her, will get a double reward; and any slave who observes Allah's right and his master's right will get a double [reward]” (Al-Jami' alsahih, 46: 723). It may be noted that this Hadith came when slaves and slavery were not forbidden in Islam. That was when Islam was just in its early stage. So it is important to note that Islamic teachings emphasized the education of both boys and girls from its embryonic phase in the 7th century and flourished as the message of Islam spread out.

On another occasion the Prophet said, "Allah Almighty makes the path to paradise easier for the one who walks on it for getting knowledge” (Al-Jami’ alsahih, 4: 2074, 2699). It can be seen that the stress is on the acquisition of knowledge, not on the sex of its seeker. There are examples in the history that show that women were regarded as scholars and teachers. For example, A'isha al-Siddiqa, the youngest wife of the Prophet, was a Hadith-narrator. She could be termed as a repository of Islamic knowledge after Muhammad (MPBUH). She was believed to have reported and taught 2,210 traditions (anything that the Prophet said or did is called tradition or Sunnah). The question arises: is it possible to teach without education? The clear-cut answer is no and hence Islam does not restrict any girl from getting education. On another occasion, 'A'isha bint Talha (may Allah be well pleased with her), the servant of Aisha at-Saddiqa, reports:

I stayed with 'A'isha. People from every city would come to me including the old ones (who would put forward questions) because they knew that I am her servant. And the students who were young would treat me like their sister and would present gifts (to 'A'isha through me). Many would also write me letters (so that I could reply them back after soliciting answers from 'A'isha. I would submit: $\mathrm{O}$ aunt! $\mathrm{Mr}$ so and so has written a letter and there is his present as well. 'A'isha would say in reply to this: O daughter! Answer his query and give him present in exchange as well. If you have nothing to give, let me know, I will give. So she would return (the present in exchange and I would send it back along with the letter). (al-Bukhari in al-Adab al-Mufrad)

The above narration is a proof that everyone should have access to education because Aishah Sadiqa's servant could read and write. So education was not confined to a certain group, rather any man or woman should be educated. Crocco, Pervez, and Katz argue that Islam was the first known religion that granted women their basic rights, including a right to own property, a right to have a say in her marriage, and a right to seek an education. The main purpose of their study was to explore how religion and culture affect women's lives in the Middle East. Their findings will be discussed in the third part of this paper. 
There are research studies that substantiate the above argument. Megahed and Lack (2011) have attempted to compare women's status and gender-educational inequalities in the Arab (Muslim populated countries) world prior to and post colonialism. They quoted Michele Brandt and Jeffrey Kaplan, "Islamists have not produced a backlash against female education due to the fact that Islam stresses education, including religious education for both men and women” (Megahed \& Lack, 2011, p. 407).

Though there appears to be no difference in the rights of education between females and males, the question may arise about the type, learning theories/viewpoints or pedagogy may be different. So the proceeding section presents the education as a whole from the perspective of Islam.

\section{Education in the Perspective of Islam}

Alavi (2008) believes, "Islam, as one of the most important religions of the world, has particular and significant educational views” (p. 5). The Islamic definition of education encompasses all learning domains of human beings. It focuses on three key words: "to know (cognitive), to love (affective), and to act (psychomotor)" (Alavi, 2008, p. 6), which makes it in line with modern definitions of education. Alavi (2008) further goes on and discusses the core of Islamic education and knowledge, and says, "knowledge is more than an idea or an attitude. Knowledge is a religious responsibility. Real knowledge cannot be obtained without the soul's purification and moral refinement" (p. 7). Gotb noted, "Islamic education pays attention to physical, moral, social, aesthetic, emotional, and intellectual cultivation” (Alavi, 2008, p. 7). Islam preaches consistency in beliefs and actions for example, "Who listen to speech and follow the best of it. Those are the ones Allah has guided, and those are people of understanding” (Zomar, p. 18). The above arguments do not draw any defining line between females and males. Rather the pressing idea here is that seeking knowledge is a religious responsibility for both males and females. Regarding pedagogy, Barumand argues that "some of the most important teaching and instruction methods that are confirmed by the Qur'an and Islamic traditions are lecture, question and answer, discussion, drama, role playing, imitation, discovery, story-telling, and self-instruction" (Alavi, 2008, p. 14).

After discussing the Islamic stance on girls' education, this paper now sheds light on some of the possible reasons for the difference in prescribed and practiced teachings of Islam with the focus on girls' education.

\section{A Gulf between the Ideal and the Real}

There are research studies that highlight the real forces behind reluctances in girls' education and how religion is being exploited to get invested interest of certain classes, organizations or cultures. For instance, Aftab (1994) found feudalism and patriarchy as major resistance raising female literacy in Pakistan. Other studies found flaws in top-level policies of Muslim countries, culture, political interest, and media role as projecting the wrong image of Islam. The rest of the paper briefly discusses the aforesaid reasons.

\section{Constitutions of Muslim Countries}

To begin with, as Esposito noted, "In Muslim countries around the world, there is a fundamental difference between what is prescribed by religious texts and what is actually practiced, a gulf between the ideal and the real” (Crocco, Pervez, \& Katz, 2009, p. 110). Their argument brings forward the discrepancies among various sections of the most powerful doctrine of Muslim countries, the Constitution. For example, Hijab explains that, 
In some Arab countries, the constitutions may guarantee [women] the right to work and the labor law may be fair, yet the family law may allow a husband to stipulate that his wife must have his consent to work outside the home. (Crocco, Pervez, \& Katz, 2001, p. 110)

Family law delegates many powers to a man including major decisions about a girl's life and hence it does not project the Islamic law in its true sense. For example, in Pakistan the Federal Shariat Court directed the President of Pakistan for amending the Muslim Family Laws Ordinance 1961 (MFLO) "so as to bring the provisions into conformity with the injunctions of Islam” (January 5th, 2000). The law may not explicitly say that, but as Naz and Zia (n.d.) have argued that "prejudicial aspect of family laws for women, as constitution of most of them is based on strong patriarchal values, where the husband always has a dominating position” (paragraph 4) makes it easy for a man to interpret it in a male dominate society. Therefore, the above situation is similar in providing girls with an opportunity to have access to education. So there is a need to review and revise (if needed) constitution to safeguard the basic rights of women in Muslim countries.

\section{Culture}

Christina, Mehran, and Mir argue that female education status should be discussed under the "consideration [of] the fact that the teachings of Islam, combined with indigenous customs and traditions, play a crucial role in determining the status of women and their education in the region”' (Megahed \& Lack, 2011, p. 403). Culture and religion are co-related. They affect each other. For instance, Parekh said, "Culture, for example, influences how religion is interpreted, its place within society, etc.; religion, on the other hand, influences the formation of cultural values and practices” (Berglund, 2011, p. 500). This have resulted in different interpretations and implementations of Islam, for example Berglund (2011) claims that "teachers and pupils of various ethnic backgrounds belonging to different theological traditions that practice Islam in a variety of ways" (p. 509). Furthermore, Hoodfar (2007) clarified that any assumption about Islam must not overlook "the fact that the interpretations and practices of Islam, like those of all other religions, are meditated through particular cultures at particular historical moments” (p. 288). The culture in most of the Muslim countries appears to be more patriarchal, in which a birth of girl is never welcomed because of an added liability and so they reluctantly send their daughters to schools. Another aspect of culture in many races among Muslim, which is contributing to the girls' passive role in society, is that males consider their females as their honor. It means men will protect their women at any cost. Hence, girls being honor of a father/brother/husband or son appear to be contributing to confining girls to home boundary only because a minor issue can cause a devastating bloodshed. The cultural norm of having a girl get married soon after she reaches puberty is another contributing factor of not opting for girls' education in the school. Rather parents prefer to educate them in households and to teach them to read Qura'an in Arabic. So there is need to propagate the actual Islamic teachings. It could be done through media or NGOs can play their roles by making it a part of their localized projects in which they work with females in their houses such as small business or knitting centers. Making necessary changes in curriculum could be its long run solution.

\section{Patriarchy}

Ramazi argues, “Many extant Islamic practices derive from patriarchal interpretations of the Qur'an in male-dominated societies where the prevailing norms influenced men's largely biased interpretations of the holy book" (Megahed \& Lack, 2011, p. 403). Moreover, Lodge (1989) explains “where the education of girls 
is compulsory Muslims wish to restrict their daughters to a curriculum which will reflect their ultimate inferior status” (Halstead, 1991, pp. 268-269). This is further substantiated by Keddie (2011) who discussed the ideas of a newly converted Muslim, Ashley. Ashley was confused about the counter practices of Islamic teachings within Muslim societies including de-valuing education for girls. Keddie (2011) analyzes this situation from the perspective of patriarchy. She argues that men want to control women and so they do not wish to expose them to the world. Afsher (2007) argues, "Muslim countries have been a matter of patriarchal power rather than faith" (p. 423). He argues that even in religious education, Muslim tend not to train women as religious leaders by not letting them enroll in religious institutions. Muslim males raised the bars by constructing legal system that would discourage women, despite the fact that there are examples in Muslim history in which females made major political decisions. For example, "Mohammad's wife Ayisha had been instrumental in shaping the early destiny of Islam. After the death of the Prophet, Ayisha, using the concept of consultation, ijma, invited the leading Muslims to select and appoint her father Abu Bakre as the Caliph of the Muslims” (Afsher, 2007, p. 423).

Therefore, patriarchy posits a major barrier in girls' education in Muslim societies. There does not seem to have some quick fix remedy for changing this approach. However, an appropriate education and empowering women could be deemed as a long-run strategy for changing patriarchy into more balanced way of living. Lack of education has been recognized as a stumbling stone in a way of women progression for example, Afsher (2007) discusses:

Muslim women did not meekly accept their fate (Mernissi, 1991), but lack of education was a major obstacle in accessing these rights. In the 19th and 20th centuries they gradually found their way back to literacy and embarked on the long struggle to reclaim their entitlements. (p. 423)

\section{Political Interest}

Education and low literacy rates have been the areas of concerns in many Muslim countries including Pakistan and Afghanistan. In 1978, USSR supported a drastic compulsory education policy. Political leaders ran a campaign against this initiative. They publicized the idea "that modern education, particularly for girls, was un-Islamic, and by promoting the belief that the Soviet Union was determined to dishonor Afghans in requiring formal education of their children, including daughters, thus undermining Islam and eroding Afghan religious life” (Hoodfar, 2007, p. 267). In countries like Afghanistan and Pakistan, politicians have invested interests in going by the will of the people. As discussed earlier, a male dominated culture devotes the whole power to men and hence politicians focus on their interests only to maintain their positions.

Because of the above stated reasons, girls' education was never a high priority not only in Muslim countries but also under British regime Greenberg (2004).

\section{Conclusion}

Islam does not forbid girls from getting education, instead it insists for education. However, flawed top-level policies, culture, political interests, patriarchy, and media role affect the interpretation of Islamic teachings. This research poses a question, why Islam as religion is being targeted and why it is made responsible for issues like girls' education? It recommends further systematic studies to address the above question. 


\section{References}

Abdulai, A. (2014). Education of women in Islam: A critical Islamic interpretation of the Quran. Religious Education, 109(1), 4-23. doi: 10.1080/00344087.2014.868203

Afshar, H. (2007). Muslim women and feminisms: Illustrations from the Iranian experience. Social Compass, 54(3), 419-434.

Aftab, T. (1994). Fighting illiteracy: What works and what doesn't: A case study of female literacy in Pakistan. Convergence, 27(4), 25-34.

Alavi, H. R. (2008). Nearness to god: A perspective on Islamic education. Religious Education, 103(1), 5-21. doi: $10.1080 / 00344080701807361$

Berglund, J. (2011). Global questions in the classroom: The formulation of Islamic religious education at Muslim schools in Sweden. Discourse: Studies in the Cultural Politics of Education, 32(4), 497-512. doi:10.1080/01596306.2011.601549

Bush, W. G. (2001). Islam is peace. Retrieved September 17, 2001 from http://georgewbush-whitehouse.archives.gov/news/releases/2001/09/20010917-11.html

Crocco, M. S., Pervez, N., \& Katz, M. (2009). At the crossroads of the world: Women of the Middle East. Social Studies, 100(3), 107-114.

Greenberg, E. (2004). Educating Muslim girls in mandatory Jerusalem. International Journal of Middle East Studies, 36(1), 1-19.

Hadith. (n.d.). In Merriam-Webster's online dictionary. Retrieved from http://www.m-w.com/dictionary/hadith

Justice in Islam. (n.d.). The religion of Islam. Retrieved from http://www.islamreligion.com/articles/376/

Keddie, A. (2011). Framing discourses of possibility and constraint in the empowerment of Muslim girls: Issues of religion, race, ethnicity and culture. Race, Ethnicity \& Education, 14(2), 175-190. doi:10.1080/13613324.2010.519970

Megahed, N., \& Lack, S. (2011). Colonial legacy, women's rights and gender-educational inequality in the Arab world with particular reference to Egypt and Tunisia. International Review of Education/Internationale Zeitschrift Für Erziehungswissenschaft, 57(3), 397-418. doi: 10.1007/s11159-011-9215-y

Qur’an. (n.d.). Retrieved from http://corpus.quran.com/translation.jsp?chapter=39\&verse=9

Rankin, B. H., \& Aytaç, I. A. (2008). Religiosity, the headscarf, and education in turkey: An analysis of 1988 data and current implications. British Journal of Sociology of Education, 29(3), 273-287. doi: 10.1080/01425690801966345

Wikipedia. (n.d.). English translation of the Quran. In Wikipedia online dictionary. Retrieved from http://en.wikipedia.org/wiki/English_translations_of_the_Quran

Wikipedia. (n.d.). List of countries by literacy rate. In Wikipedia online dictionary. Retrieved from http://en.wikipedia.org/wiki/List_of_countries_by_literacy_rate

Zaid, H. (2011). God's pronoun. Retrieved from http://eshaykh.com/doctrine/gods-pronoun/ 